\title{
Strategic Dimensions of Neoliberal Globalization: The Exporting of Labor Force and Unequal Exchange
}

\author{
Raúl Delgado Wise, Humberto Márquez Covarrubias \\ Universidad Autónoma de Zacatecas, Zacatecas, México \\ Email: rdwise@estudiosdeldesarrollo.net,hmarcov@gmail.com
}

Received March 13 ${ }^{\text {th }}$, 2012; revised April $16^{\text {th }}$, 2012; accepted April 27 $7^{\text {th }}, 2012$

\begin{abstract}
In addition to environmental degradation and financial speculation, neoliberal globalization has created a complex strategy of capital internationalization led by large multinational corporations that is driving labor costs down to extreme levels. This strategy is based, on the one hand, on the establishment of global commodity chains based on outsourcing schemes and intra-firm trade, which operate in peripheral nations and in the form of enclaves; on the other, it employs international labor migration as a means to lower labor costs in central countries. Both mechanisms comprise a new rung in the international division of labor: the export of labor. This process has led to new forms of unequal exchange that are much more predatory than those involved in the exchange of raw materials for industrial products. This has led to a reintegration of a subordinate periphery to the center, increasing asymmetries between countries and pushing social inequality to unprecedented levels. The purpose of this paper is to empirically and conceptually analyze these fundamental aspects of contemporary global architecture.
\end{abstract}

Keywords: Labor Export; Unequal Exchange; Uneven Development; Neoliberal Globalization; Crisis

\section{Introduction}

In the early 1970s, labor constraints were listed as one of the main obstacles to global capital accumulation (Harvey, 2003). The big challenge in order to overcome this obstacle was to lower the cost of labor. The concomitant strategies employed by large multinational corporations (MNCs) under the governmental support of the world's most powerful countries, led by the United States and international agencies headed by the World Bank (WB), the International Monetary Fund (IMF) and the World Trade Organization (WTO), have triggered a profound process of capitalist restructuring. That is, the so-called neoliberal globalization, which is characterized by:

1) The internationalization of capital. The global economy's expansion strategy is based on a profound restructuring of the global economic framework through the establishment of outsourcing and/or intra-firm trade among big corporations, the influence of which extends across the world. This form of expansion seeks the economic reinsertion of peripheral countries with abundant and cheap human and natural resources; here, new export platforms operate in the form of enclaves. Currently, between 55 million (Robinson, 2008) and 66 million workers in the southern hemisphere (Singa Boyenge, 2007) work in this type of plants. The operating agents behind this strategy are large manufacturing, financial, agricultural, trade and services corporations (Robinson, 2008).

2) Financialization. Financial capital generates speculative strategies that channel investment funds, sovereign funds and social surplus toward new financial instruments that offer high profit margins in the short term but risk causing recurring crises and massive fraud, all of which obstructs and affects the functioning of the real economy (Foster \& Magdoff, 2009; Bello, 2006).

3) Environmental degradation. Biodiversity, natural resources and community and national assets are being privatized for the benefit of big corporations who favor profits over social and environmental costs. This results in increased environmental exploitation, pollution, famine and disease. It is also leading to changes in climate (global warming and more frequent and intense extreme weather events) that endanger the symbiosis between human society and nature (Foladori \& Pierri, 2005).

4) The restructuring of innovation process. Technological advances in computing, telecommunications, biotechnology, new materials and nanotechnology cater to the needs of large corporations in search of higher profits. Scientific and technological work is restructured via mechanisms such as outsourcing and offshore-outsourcing, which enable these corporations to have a mass of southern hemisphere scientists at their service while capitalizing on benefits and transferring risks and responsibilities by amassing patents. This leads to an unprecedented commodification of scientific work under a short-term view and with little social concern (Freeman, 2005; Lester \& Piore, 2004).

5) Labor precarization. One of the main forces behind the new capitalist architecture is the cheapening of labor costs. Massive oversupply of labor from underdeveloped countries in Africa, Latin America, Asia and the former communist bloc supports this dynamic. This leads to the increasing transnationalization, differentiation and precarization of labor markets. As a result, new divisions within the working class are fostered through the introduction of national, racial and cultural labor hierarchies that enable large corporations to enjoy havens of cheap and flexible labor (Harvey, 2007; Schierup, Hansen, \& Castles, 2006).

6) The new migration dynamics. While migration is a historical process that has always exhibited certain continuities, it is changing drastically in the context of neoliberal globalization, 
acquiring a new profile and dynamic. On the one hand, it is characterized by: a) strong pressure to emigrate in the main sending areas given the absence of job opportunities, and b) the increased vulnerability of these new labor migrants, who are subjected to extremely exploitative conditions. On the other, new migration patterns mainly flow from the southern to the northern hemisphere (82 million) and within the south (74 million), with a significant degree of internal migration (750 million). All of this reconfigures the map of labor in a context of precariousness and turns migration into a key element of the capitalist restructuring process as a whole (UN, 2004, 2006 and 2010; Delgado, Wise \& Márquez, 2007 and 2009).

In short, the restructuring process that characterizes capitalist neoliberal globalization has nothing to do with a "free market" ideology but a growing monopolization of production, services and global trade, accompanied by progressive labor exploitation and environmental degradation; taken together, these comprise an exploitative, parasitic, rentier-based and predatory phase of global capitalism (Petras \& Veltmeyer, 2000; Stiglitz, 2002).

Starting from these fundamental issues, the purpose of this study is to examine two essential features of neoliberal globalization: the export of labor and unequal exchange. As we shall see in the following sections, they are both linked to the dynamics of uneven development that characterize contemporary capitalism and are the basis for its poor, inconsistent and unsustainable performance.

\section{Notes on the Performance of Contemporary Capitalism}

The following data and indicators highlight the unique pattern that characterizes neoliberal globalization and are also intended to expand theoretical and conceptual perceptions of its nature. We are primarily interested in drawing attention to some core aspects of its performance, mainly in the field of production living aside the financial and environmental aspects. We do not seek to deny or dismiss the ingrained dialectic relationship between the latter two dimensions and the first but unravel what happens in the field of the so-called "real economy" by using the method of political economy, placing special emphasis on the transformations taking place in capital/labor interactions.

\section{The Massive Oversupply of Labor ${ }^{1}$}

With the incorporation of the former Soviet Union, China and India to the global capitalist market, labor supply for the system essentially doubled, increasing from 1.46 to 3 billion (Freeman, 2005). To this we must add the violent and overwhelming liberalization of the labor force that has taken place in peripheral economies as a result of structural adjustment programs which, as discussed below, have served to dismantle these economies and promote their asymmetric and subordinated reintegration into neoliberal globalization.

\section{The Growing Precarization of Labor}

Massive labor oversupply has led to a drastic shift in dyna-

\footnotetext{
${ }^{1}$ The notion of labor oversupply contravenes orthodox concepts of "balance" between supply and demand. Our use of the "over" prefix has a double purpose: first, it emphasizes the fact that contemporary capitalism is characterized by a labor overpopulation or reserve labor army of enormous proportions (absolute overpopulation, in Marxist terms) and, second, that this overcrowding is due to changes in the institutional framework associated with new business strategies, which are part of the ongoing process of capital internationalization and are based on cheapening labor costs.
}

mics and labor market performance. Instead of an upwards "win-win" convergence between the wages earned in developed and underdeveloped (or peripheral) nations and as stipulated by neoliberal precepts, we are experiencing the exact opposite: a process of increasing economic polarization between countries accompanied by progressive deterioration and a downward convergence in the living and working conditions of the entire working class. It is enough to point out that, currently: 1) 1530 million workers (just over half of the world's labor force) work in conditions of vulnerability that include no job security or access to minimum labor rights, and 2) 630 million workers (one in every four) earn less than $\$ 1.25$ dollars per day, which places them a context of extreme poverty (ILO, 2011).

\section{The Increase in South-North and South-South Labor Migration}

Given the massive oversupply of labor and the growing deterioration of living and working conditions for the bulk of the working class, migration-particularly that from peripheral to central countries - has become a necessity and not merely an option for family subsistence. For this reason, it is increasingly turning it into forced displacement.

Under these circumstances, the amount of migrants (mostly from the periphery) has grown considerably over the past three and a half decades, from 84 million in 1975 to 214 million in 2010 (see Figure 1). Moreover and in the name of "national security," migrants are increasingly subject to exploitative conditions, extreme vulnerability and social exclusion (Delgado Wise, Márquez, \& Puentes, 2009).

The North-South flow of remittances has been increasing at an even more significant rate, rising from 57 billion dollars in 1995 to 325 billion dollars in 2010 (World Bank, 2010) (see Figure 2). This has led to the reintegration of a subordinated periphery to the center, increasing asymmetries between countries and pushing social inequality to unprecedented levels. Some international organizations like the WB and the InterAmerican Development Bank (IDB) disregard the actual nature of remittances (i.e., a fraction of reduced wages earned in destination countries) and twist reality while envisioning these funds as a supposedly inexhaustible source of resources for the development of sending countries. This is, obviously, a great myth or, as stated by Devesh Kapur (2004), a new development mantra that distorts reality and masks the emergence of new

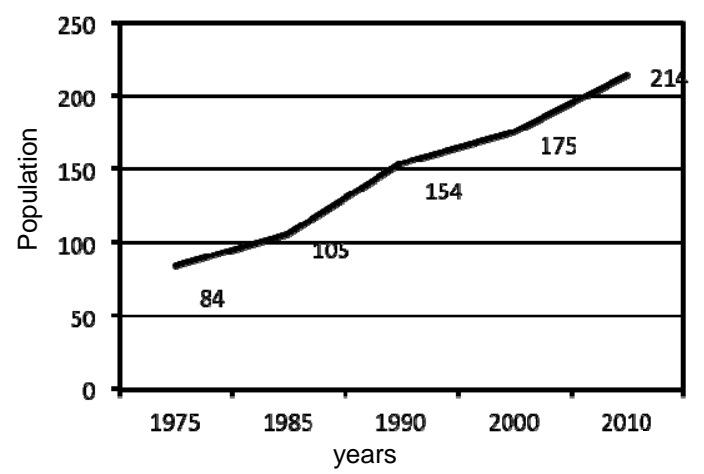

Source: CONAPO (Consejo Nacional de Población) and World Bank, 2010.

Figure 1.

International migrants worldwide. 


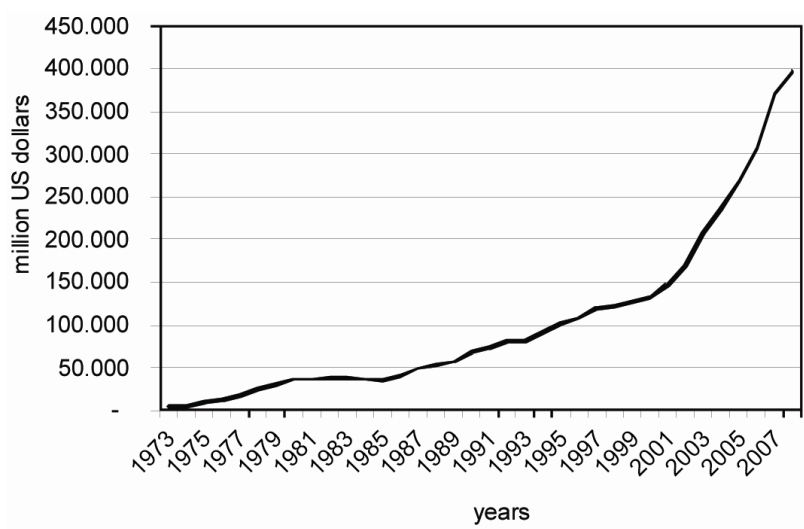

Source: World Bank.

Figure 2.

Remittances in the world (million US dollars).

forms of unequal exchange.

\section{Growing Social Inequalities}

Although, between 1990 and 2007, employment across the world grew by $30 \%$, this growth could not meet the increasing and overwhelming demand for jobs. It also led to a very unequal distribution of labor supply, particularly along the NorthSouth horizon. This resulted in a marked differentiation and precarization of labor markets, with profound implications in terms of social inequality. This grew in an unprecedented manner on varying levels and degrees and was accompanied by a shrinking middle class and the progressive dismantling of the welfare state. We must take into consideration that a report issued by the International Labour Organization (ILO, 2008) reveals that, in 51 of the 73 countries with available data, the share of wages in gross domestic product (GDP) decreased significantly between 1990 and 2007. The biggest drops were in Latin America and the Caribbean (13\%), followed by Asia and the Asian Pacific (10\%) and, finally, the more advanced economies (9\%). This, in turn, resulted in a drop in income distribu- tion (measured by the Gini coefficient) in approximately two thirds of studied countries.

The U.S. case is paradigmatic in this context: household inequality, as measured by the Gini coefficient, underwent a significant increase over the neoliberal period (see Figure 3). Moreover, in 2009 and according to data from the U.S. Census Bureau, the highest income quintile of U.S. households accounted for $50.3 \%$ of revenue, while the lowest only comprised $3.4 \%$. These are historic levels of inequality and even exceed those of the 1920s.

\section{The Relative Decrease in Developed Countries' Capacity for Innovation}

In spite of what appeared to be a constant in the history of capitalism, the rate of innovation capacity in developed countries declined from 0.876 in 1995 to 0.869 in 2001 (see Table 1).

This phenomenon, which entails significant changes in the patterns and role played by productive force development in the dynamics of capitalist accumulation, is associated to the restructuring of innovation process mentioned in the preceding paragraph. This restructuring is spurred by cheap labor costs in

Table 1.

Innovation capability index*.

\begin{tabular}{lll}
\hline & 1995 & 2001 \\
\hline Developed countries & 0.876 & 0.869 \\
New EU members & 0.665 & 0.707 \\
Southeast Europe and CIS & 0.602 & 0.584 \\
Southeast and East Asia & 0.492 & 0.518 \\
Latin America and the Caribbean & 0.375 & 0.360 \\
Southern Asia & 0.223 & 0.215 \\
Sub-Saharan Africa & 0.157 & 0.160 \\
\hline
\end{tabular}

Source: UNCTAD, 2005; *This index combines indicators of technological activity (R \& D personnel, patents and scientific publications) with human capital indicators mainly related to education levels.

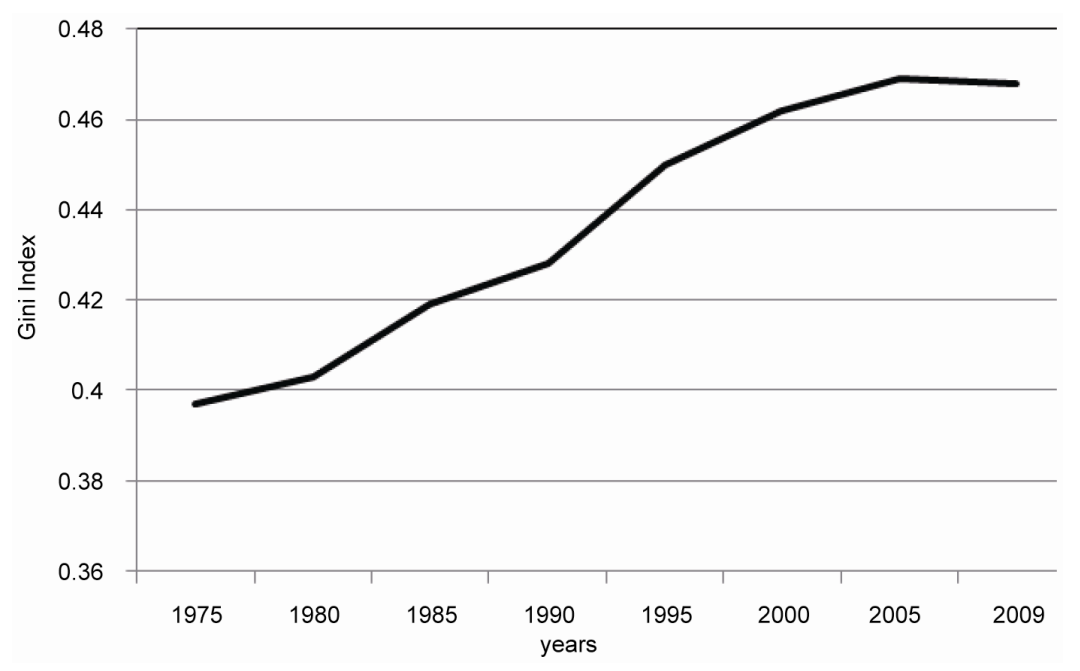

Source: U.S. Census Bureau. http://www.census.gov/hhes/www/income/data/historical/inequality/taba2.pdf.

Figure 3.

United States: Household income inequality measured by the Gini coefficient. 
scientific/technological activities, where the incorporation of skilled and highly qualified workforce from the periphery plays an increasingly important role, either via immigration or through the establishment of outsourcing platforms in peripheral countries (i.e., offshore outsourcing).

\section{The Low Rates of Economic Growth}

In contrast to post-war annual rates of economic growth (GDP), which globally averaged 5.8\%, growth fell throughout the neoliberal period to $3.5 \%, 3.2 \%, 2.9 \%$ and $2.6 \%$ in the 1973-1980, 1980-1990, 1990-2000 and 2000-2009 periods, respectively (see Figure 4).

It must be added that, toward the end of the first decade of this century, a general crisis of global capitalism broke out. Centered in the United States, this crisis has affected multiple aspects of the current system (Márquez, 2009 and 2010):

- Financial. Financial capital overflow produces bubbles that affect the socioeconomic fabric and lead to a global economic depression (Foster \& Magdoff, 2009; Bello, 2006).

- Overproduction. Excess capital circulating the global economy that cannot find conditions for implementation in the field of production due to falling profit margins and a decline in effective demand (mainly because of wage and income containment for the bulk of the population) creates a crisis of overproduction (Bello, 2006).

- Environmental. The degradation of natural resources, climate change and the commodification of the environment contribute to the destruction of nature. This manifests itself as a structural rupture in the material bases for the production and reproduction of human life (Foladori \& Pierri, 2005).

- Social. Growing social inequality, the dismantling of the welfare state and the breakdown of systems of subsistence accentuate poverty, unemployment, violence, insecurity and labor precariousness, adding pressure to migrate (Harvey, 2007; Schierup, Hansen, \& Castles, 2006).

This crisis challenges the prevailing style of globalization and, in a more profound way, the global systemic order: the current system is devastating the main sources of wealth, work and nature itself, all of which have been overexploited and degraded to the point they threaten the fabric of civilization itself.

\section{Uneven Development and the Exporting of Labor Force}

It is clear that the nature of contemporary capitalism has been

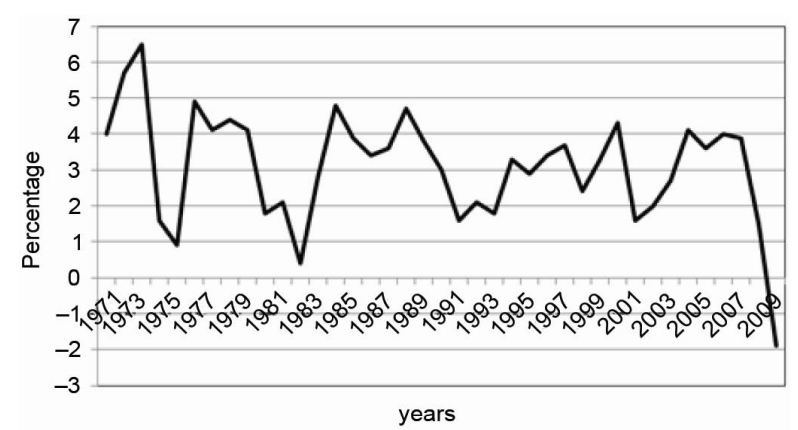

Source: World Bank.

Figure 4.

World economy growth rates. inaccurately represented and distorted by a bland and apologetic notion of globalization that condones the increase in international flows of capital, information, technology and workforce. Beyond this partial and limited vision, which rests on blind faith in a supposedly free and self-regulating market as a route to achieving a just and equitable society, the past three and a half decades have been characterized by a project of capitalist expansion that has had severe consequences in terms of development and social justice. The concept of uneven development, framed by the notion of imperialism, is particularly useful for describing and analyzing this situation given that it refers to the historical process of economic, social and political polarization between regions, nations and classes derived from the dynamics of capital accumulation, the international division of labor and different modes of class conflict. One of the most conspicuous outcomes of this process is the unprecedented expansion of social inequalities that characterizes contemporary capitalism and has resulted in an excessive concentration of capital, power and wealth in the hands of a few while the majority of the population has seen a progressive downgrading in their living and working conditions. This process is also evident, on a spatial level and with different emphases, ${ }^{2}$ in the expansion and deepening of the asymmetries between the main developed countries and most peripheral or underdeveloped nations.

We do not wish to characterize capitalist development as a simple dichotomous process, or offer a Manichean view of its superficial aspects. On the contrary, we seek to unravel the nature of the process of uneven development that characterizes contemporary capitalism, which is marked by the introduction of extreme forms of elitist appropriation of the economic surplus, both in the periphery and the advanced industrial nations of the center. In this sense, the massive influx of cheap, flexible and disorganized labor from the periphery constitutes a crucial aspect in the strategy of capital internationalization.

The neoliberal structural adjustment policies promoted by the IMF and the WB in collusion with the WTO are expressly designed to promote this strategy and create a triple effect in peripheral economies: 1) the dismantling of the domestic marketoriented economic structures and their rearticulation into the international market; 2) the restructuring of the labor market in order to generate a growing and overwhelming surplus population; and 3) an outflow of surplus labor through labor migration (Delgado Wise \& Márquez, 2007). This process promotes the reinsertion of the periphery into the sphere of global capital in two complementary ways:

1) The establishment, expansion and deepening of global commodity chains by transferring parts of the production process to peripheral regions with an abundance of cheap labor. ${ }^{3}$ Essentially, this is a strategy of international expansion carried out by large MNCs and based on operational outsourcing and intra-firm trade, which triggers a peculiar activity in peripheral economies: the indirect or disembodied export of workforce. We characterize this type of export thusly because the main component of the exported goods is the value of the producing

\footnotetext{
${ }^{2}$ There are important exceptions to this trend, including state-led industrialization processes in various Asian countries that deviate from the measures promoted by the Washington Consensus (Cypher \& Dietz, 2009). Similarly, we have the short-term impacts of the recent commodity boom.

${ }^{3}$ Although we do use the concept of global commodity chains coined by Gary Gereffi (2001), we do not share his optimistic view regarding the scope and implications of globalization.
} 
labor as a result of the enormous volume of imported supplies associated with production links abroad. This, in addition to reducing the local impact of manufacturing operations to meager wage earnings (and, in the best of cases, a limited multiplier effect by way of consumption) leads to the configuration of new enclave economies operating as appendages in global commodity chains. Add to this the fact that the supply of imported materials is often made via foreign operations or through tax-exempt or subsidized manufacturing or assembly contracts (outsourcing) that are free from any liability regarding labor rights and potential environmental damage. All of this results in a significant lowering of the production costs for large MNCs, which gain unrestricted access to the periphery's abundant and available supply of cheap labor (Delgado Wise \& Márquez, 2006; Cypher \& Delgado Wise, 2010).

2) The movement of surplus population from the periphery to developed regions via labor migration constitutes a second strategy. This movement, characterized as direct export of labor, does not only cover the structural deficits in labor demand suffered by developed economies, which have an aging population and an inadequate supply of domestic labor force to meet the labor demand; it simultaneously increases job competition in various sectors of the receiving economies and triggers a downward trend in wages for the entire working class. Importantly, this process does not derive from a simple game of supply and demand in the labor market, but is part of a deliberate business strategy. ${ }^{4}$

Thus, the direct and indirect export of labor plays a key role in the neoliberal plan. It delineates the contours of a new international division of labor that implies an asymmetric model based on the reintegration of peripheral nations to the global capitalist system. It constitutes, in essence, a higher phase in the commoditization of the workforce available in the international market, leading to a progressive reduction in the quality of the living and working conditions for the majority of the employed population and their dependents. As we shall see in the next section, this translates into a progressive devaluation and cheapening of the labor force and the emergence of extreme labor exploitation or superexploitation. These conditions are not merely specific to the periphery, as suggested by Marini in his theories regarding underdevelopment and dependence (1973); they expand to central nations through labor migration which, as we already pointed out, acquires the character of forced displacement.

As mentioned before, the new global architecture includes an exorbitant flow of financial/speculative capital and environmental destruction, ${ }^{5}$ which intensify the contradictions inherent to the system and emphasize its bias toward expansion and the

\footnotetext{
${ }^{4}$ A clear example is the restructuring of manufacturing in the United States through assembly or manufacturing operations and intra-firm trade, which have moved significant parts of the production process abroad. This has severely affected domestic employment, manifesting in the loss of almost four million jobs in this sector between 1994 and 2008. In addition to this measure, which gives corporations access to foreign paradises of cheap labor, there is an ongoing trend to replace native workers with immigrant labor force (e.g., Mexican migrants). Their wages are, on average, half of those earned by natives (Delgado Wise, Marquez, \& Rodriguez, 2009).

${ }^{5}$ Natural biosphere resources have been increasingly incorporated into capitalist market logic. Since the goal is to maximize profit in the shortest amount of time possible, these resources are being depleted. Many scientists and institutions have called attention to serious phenomena such as global warming, climate change and the loss of biodiversity, which generate substantial imbalances in natural/social relationships, to the extent that they now threaten the reproduction of human life on the planet.
}

deepening of both the geopolitical and geo-economic imbalances that include social inequality.

\section{Emergence of New Forms of Unequal Exchange}

The concept of unequal exchange is crucial to the strategic and structural transfer of surplus across global commodity chains, which is also at the base of the periphery's asymmetric reintegration into neoliberal globalization. Despite the central role once played by this concept to explain the dynamics of uneven development and unravel the nature of the link between developed and underdeveloped, peripheral or dependent nations (e.g., the theories of the Economic Commission for Latin America-CEPAL ${ }^{6}$ - and dependency theorists ${ }^{7}$ ) it has yet to be included in analyses of contemporary capitalism. It is important to note that the bulk of the discussion of unequal exchange has been and remains limited to the analysis of the international division of labor that characterizes the periphery as a supplier of raw materials and developed countries as suppliers of industrial products. While this division remains in force for a significant number of peripheral countries, it has ceased to exclusively define North-South relations. Some newly industrialized peripheral countries (mainly in the Asian region) increasingly serve as suppliers of industrial goods. ${ }^{8}$ More important is the fact that this classic form of unequal exchange has incorporated a new and increasingly central one: direct or indirect labor force export. $^{9}$

To undertake an analysis of this kind, it should first be noted that mechanisms of unequal exchange involve much more unfavorable terms for the periphery than those implicit in the exchange of raw materials for manufactured goods. On the one hand, the indirect export of labor force associated to peripheral nations' role as appendages to global commodity chains involves a net transfer of profits. This is an extreme form of unequal exchange, since it involves extracting almost all the economic surplus generated by the workforce employed in the manufacturing and assembly plants. ${ }^{10}$ This export enclave mechanism inhibits any prospect of economic growth and development arising from export operations made (under the guise of manufacturing exports) by the peripheral nation. In fact, their actual contribution to the national accumulation process is li-

\footnotetext{
${ }^{6}$ The Prebisch-Singer hypothesis regarding the worsening nature of trade conditions in the early 1950s was particularly important in the development of ECLAC theories (Prebisch, 1986). Celso Furtado's work was also very influential (Mallorquin, 2007; Bresser-Pereira, 2007).

${ }^{7}$ Beyond the heated Marxist debates of the 1970s and 1980s (Samir Amin, et al., 1971; Críticas de la Economía of Política, 1979), there is no doubt that the pioneering writings of Emmanuel (1973, originally published in 1969) on the nature of unequal exchange had a strong influence on dependency theorists. There are, however, many variants of dependency analysis and the theoretical work on unequal exchange offers analytical perspectives that require further development must be adapted to the realities of contemporary capitalism (Brewer, 1980, 208-232; Munck 2000).

${ }^{8}$ In his famous writings following his hypothesis (with Raul Prebisch) about the deteriorating terms of trade, Hans Singer (1975) anticipated such a situation when he sought to go beyond a simple analysis of changes in relative prices between two classes goods and considered the problem of different production structures between the center and the periphery, placing an emphasis on technical progress.

${ }^{9}$ As noted above, an estimated 55 to 66 million laborers work in assembly plants located in the periphery while 70 million southern laborers work in the developed North.

${ }^{10}$ Under the proprietary nature of intra-firm activities, closely associated to surreptitious outsourcing activities, the magnitude of these transfers can be easily concealed in company accounts and an exact measurement is therefore nearly impossible.
} 
mited to meager wage earnings that take advantage of huge income differences between countries and, in the best of cases, a small multiplier effect by way of consumption. Moreover, the installation and operation of assembly plants in peripheral countries is accompanied, as noted earlier, by subsidies and tax exemptions that affect the social capital of the host country and generate collateral damage that includes the narrowing, differrentiation and precarization of labor markets, along with environmental degradation. Another aspect of indirect labor export that has become particularly important nowadays is the creation of complex scientific/technological developments in the periphery that are linked to the restructuring of innovation systems in some of the more developed countries. Under subcontracting schemes, intangible goods of even greater strategic importance than the net profit from manufacturing and assembly plants are transferred abroad. By this we mean the transfer of the capacity for development and progress, which takes the form of competitive advantage and an ability to generate extraordinary profits.

On the other hand, the direct export of workforce via labor migration involves the transfer of anticipated future benefits arising from expenditures on the training and social reproduction of the migrants. These costs, as demonstrated in the case of Mexico, the world's major migrant sending nation, are not compensated by the flow of remittances (Delgado Wise, Márquez, \& Rodríguez, 2009). In demographic terms and for peripheral countries that are located in an advanced stage of demographic transition, this transfer means the export of their demographic dividend (i.e., the productive age population that maintains children and older adults). In a deeper sense, this shift implies the loss of the most important resource for the accumulation of capital in the country of origin: its workforce. The export of highly skilled labor force exacerbates the problem, seriously reducing the country of origin's capacity for self-beneficial innovation and the promotion of intensive technological development projects.

Analyzing these new forms of unequal exchange is a theoretical, methodological and empirical challenge that requires changes in the perception and characterization of the conventional categories used to interpret contemporary capitalism. However, while recognizing the significant contributions of ECLAC to the understanding of this phenomenon (especially regarding the central role given to technical progress), it is important to add that Marxist theories of unequal exchange (in the strict and general sense) provide a solid and fertile conceptual ground for theorizing the emerging forms of unequal exchange involved in the labor export. On the one hand and strictly speaking, unequal exchange centers on wage differentials arising from population mobility barriers (which, in more precise terms, relate to differential rates of surplus value) and, on the other and in a broad sense, it adds those emanating from various organic capital compositions, (i.e., differentials in scientific/technological progress in the involved countries). We must take into account the fact that the internationalization of capital seeks to cheapen labor costs through global commodity chains (including those involving highly qualified workforce) and maximize the transfer of surplus between peripheral and developed countries precisely by deepening wage differentials. This line of reasoning could be extended to an analysis and conceptualization of the unequal exchange relationships involved in international labor migration.

It must be added that, in addition to the material and human losses suffered by countries of origin, which are not compensated by remittance flow, direct export of labor also entails invaluable costs and risks for migrants and their families. We should not forget that the migration flows that distinguish neoliberal globalization assume the character of forced migration (i.e., the movement of people who are literally are forced from their territory given the lack of employment opportunities and forms of family support in their places of origin). The journey entails many risks and dangers, particularly for the most vulnerable groups, including permanently precarious working conditions and social exclusion in places of destination.

Everything that has been said up to this point shows that the view promoted by some international agencies, which relegate development responsibilities in places and nations of origin to migrants is not only an absurd distortion of reality but an attempt to conceal the system of unequal exchange embodied by neoliberal globalization. Among the assumptions that fuel this political-ideological view we are told that: 1) migration is a source of development for the sending country, with migrants as the agents and remittances as a driving force; 2) migration has its own self-generated dynamic and does not obey structural causes; 3) migration represents a burden on the host country and remittances a leakage of its resources; 4) migrants are responsible for the deteriorating employment and living conditions in the host society, and 5) migration is a poverty-fighting strategy that economically empowers the poor (Delgado Wise, Márquez, \& Rodríguez, 2009).

In addition to being unilateral and biased, this concept is a contradiction in terms: it is precisely underdeveloped conditions (and, in particular, the dynamics of neoliberal globalization) that increase underdevelopment and North-South asymmetries, leading to labor emigration and the new migration dynamics. In short, this is a distortion of reality that seeks to create the illusion that migrants and remittances (presented as an endless flow of monetary resources) can and should become a force for development in countries of origin. ${ }^{11}$

The contributions made by immigrants to the host economy and society are often bypassed. Instead of publicly acknowledging these contributions, the states of receiving countries (which serve the interests of the ruling class and large corporations) utilize a discriminatory discourse that presents immigrants as a social burden and criminalizes them, to the point that they are presented as a risk to national security. In a similar vein, migrants become the civilian population's favorite scapegoats and are blamed for the evils caused by neoliberal globalization: the dismantling of the welfare state, the decline of the middle class, falling wages, and unemployment, among others. The stigmatization of the migrant workforce effectively devalues it and has a domino effect across the whole of the working class in host societies.

Finally, it is important to note that, in the context of this ideological construction, the strategic/structural causes of forced migration are ignored, as are those behind labor export and associated unequal exchange patterns.

\section{Concluding Remarks}

Throughout this paper we have attempted to provide empirical and conceptual elements that can unravel crucial aspects of

\footnotetext{
${ }^{11}$ This does not seek to bypass the contributions made by migrants and their organizations to development in communities and places of origin, which involve great sacrifices. We want to emphasize how this essentially constitutes a salary transfer that, in its very nature, is a product of the unequal trade relations that characterize contemporary capitalism (Márquez, 2007).
} 
neoliberal globalization. This is just preliminary work and it merits further development in at least three strategic areas:

- First, the critical reconstruction of the field of development studies. The prevalence of so-called single thought, ${ }^{12}$ which rests on the idea that the free market is the mechanism that efficiently allocates resources and generates schemes of economic convergence between countries and their peoples, has clearly failed. In this sense, we must rethink the development of peripheral countries from new theoretical and political perspectives that adapt Latin American critical thought and the experiences of other regions to contemporary reality. These ideas should promote profound changes in the structural, political and institutional framework of peripheral countries, moving toward a new global architecture that reduces social inequalities, asymmetries between countries, and establishes a harmonious relationship with the environment.

- Second, the need for further theoretical, conceptual and empirical analysis regarding the nature of neoliberal globalization. As this paper shows, neoliberal globalization constitutes an exploitative, parasitic rentier-based and predatory mode of capitalist expansion that departs from the pathways of the "progressive" historical development of capitalism. Instead of relying on the development of productive forces as the engine of the accumulation process, it bases itself on opportunities created by large MNCs to make very high profits in a quick and easy way: labor overexploitation (which takes advantage of the massive oversupply of workforce in the periphery and former socialist countries), financial speculation, and the irrational exploitation of natural resources. All of this requires building new analytical categories that can unravel the complex process of capital internationalization that has been underway for the past three and a half decades. Among other things, we must dissect the dynamics of uneven development that characterize the current phase of imperialist domination-specifically: 1) geographical dispersion/concentration of capital along a North-South axis, which is generated by the MNCs outsourcing of production processes to peripheral regions (Sassen, 2007); ${ }^{13} 2$ ) the retrogressive development dynamics that unfold in the periphery

\footnotetext{
${ }^{12}$ This concept was popularized by Ignacio Ramonet in an article published in Le Monde Diplomatique in 1995. It refers to a social vision and ideology that claims natural and unquestionable exclusivity and supports the basic tenets of neoliberal ideology.

${ }^{13}$ It is important to stress that the strategy of capital internationalization led by large MNCs has nothing to do with the alleged disappearance of the nation-state suggested by postmodern ideologies or the supposed dismantling of imperialism, as proclaimed by Michael Hardt and Antonio Negri (2000) in their famous book, Empire.

${ }^{14}$ In the context of neoliberal globalization, some peripheral economies have restricted their export platforms to basic outlines of primarization. Even worse those who have adopted an extreme neoliberal ideology and entered fully into the dynamics of labor export have taken two steps back in their exporting dynamics, triggering what could be characterized as processes of "underprimarization" in their export platforms, with all the implied consequences in terms of a reduction of domestic accumulation capacity and surplus transfer to foreign soil (Cypher \& Delgado Wise, 2010).

${ }^{15}$ This requires empirical evidence that can demystify the idea that "free trade" agreements open avenues for development in peripheral countries as well as highlight their true nature as investment-driven economic restructuring tools used by MNCs, fostering the destructive and rearticulating nature of neoliberal structural adjustment programs. Also, it is important to demystify prevailing views regarding the supposed benefits international migration brings countries of origin and counter the criminalization of migrants, which fuels xenophobia and racial and gender discrimination.
}

as a result of labor export and its dual character; ${ }^{14}$ 3) the characteristics of the new international division of labor and emerging forms of unequal exchange, as well as associated forms of informal and precarious employment. This, in turn, requires the construction of new indicators capable of capturing this reality and demystifying dominant conceptions regarding the character and nature of contemporary capitalism. $^{15}$

- Third, the construction of an agent of social transformation. The globalization project led by the United States has a limited number of beneficiaries to a small capitalist elite and has already lost its popularity given the overwhelming mass of excluded and worldwide causalities. This has triggered the need for a drastic change in the economic, political, social, cultural and environmental fabric. However, this degree of social transformation is not feasible without the participation of organized civil society, both in the form of movements and struggles carried out by a diversity of agents. Building an agent of transformation calls not only for an alternative kind of development that is theoretically and empirically grounded, but also for channels of dialogue, the sharing of experiences, and the need to reconcile interests and visions and build partnerships, both across SouthSouth and South-North axes.

\section{REFERENCES}

Amin, S. (1971). Imperialismo y comercio internacional. El intercambio desigual. Mexico: Siglo XXI.

Bello, W. (2006). The capitalist conjuncture: Over-accumulation, financial crises, and the threat from globalisation. Third Word Quarterly, 27, 1345-1368. doi:10.1080/01436590601027222

Bresser-Pereira, L. (2007). Method and passion in Celso Furtado. In E. Pérez, \& M. Vernego (Eds.), Ideas, policies and economic development in the Americas (pp. 9-30). London: Routledge. doi:10.4324/9780203964026.ch2

Brewer, A. (1980). Marxist theories of imperialism. London: Routledge and Kegan Paul.

Críticas de la Economía Política (1979). El intercambio desigual. Mexico: El Caballito.

Cypher, J., \& J. Dietz (2009). The process of economic development (3rd ed.). London: Routledge.

Cypher J. M., \& Delgado Wise, R. (2010). Mexico's economic dilemma. The developmental failure of neoliberalism. Lanham, MA: Rowman \& Littlefield.

Delgado Wise, R., \& Márquez, H. (2007). The Theory and practice of the dialectical relationship between development and migration. $\mathrm{Mi}$ gración y Desarrollo, 9, 5-25.

Delgado, R., \& Márquez, H. (2009). Understanding the relationship between migration and development: Toward a new theoretical approach. Social Analysis, 53, 85-105. doi:10.3167/sa.2009.530305

Delgado Wise, R., Márquez, H., \& Rodríguez, H. (2009). Seis Tesis para Desmitificar el Nexo entre Migración y Desarrollo. Migración y Desarrollo, 12, 27-52.

Delgado Wise, R., Márquez, H., \& Puentes, R. (2009). Elementos para replantear el debate sobre migración, desarrollo y derechos humanos. URL (last checked 2-5 November 2009). http://migrantologos.mx/lecturaseminario/Mig\%20Des\%20y\%20DH \%20julio\%202010.pdf

Delgado Wise, R., \& Invernizzi, N. (2005). Differences Behind the Appearances: Export Growth, Technological Capabilities, and Development in Mexico and South Korea. Canadian Journal of Development Studies, 3, 409-421.

Emmanuel, A. (1972). El intercambio desigual. Mexico: Siglo XXI.

Foladori, G., \& Pierri, N. (2005). Sustentabilidad? Desacuerdos sobre 
el desarrollo sustentable. Mexico: Miguel Ángel Porrúa.

Foster, J. B., \& Magdoff, F. (2009). The Great Financial Crisis: Causes and Consequences. New York: Monthly Review Press.

Freeman, R. B. (2005). What really ails Europe and America: The doubling of the global workforce. URL (last checked 18 April 2012). http://www.theglobalist.com/storyid.aspx?StoryId=4542.

Freeman, R. B. (2005). Does globalization of the scientific/engineering workforce threaten U.S. economic leadership? URL (last checked 18 April 2012). http://www.nber.org/papers/w11457

Gereffi, G. (2001). Las cadenas productivas como marco analítico para la globalización. Problemas de Desarrollo, 125, 9-37.

Hardt, M., \& Negri, A. (2000). Empire. Cambridge, MA: Harvard University Press.

Harvey, D. (2007). Neoliberalism as creative destruction. The Annals of the American Academy of Political and Social Science, 610, 21-44. doi:10.1177/0002716206296780

International Labour Organization (2008). World of work report 2008. Income inequalities in the age of financial globalization. Geneva: OIT.

Organización Internacional del Trabajo (2011). Tendencias mundiales del empleo 2011: El desafío de la recuperación del empleo. Geneva: OIT.

Kay, C. (2002). Why East Asia overlook Latin America. Third World Quarterly, 23, 1073-1102. doi:10.1080/0143659022000036649

Kapur, D. (2004). Remittances: The new development mantra? G-24 Discussion Paper Series, 29, 1-34.

Lester, R., \& Piore, M. (2004). Innovation. The Missing Dimension. Cambridge, MA: Harvard University Press.

Lozano, F., \& Gandini, L.(2009). La emigración de recursos humanos calificados desde países de América Latina y el Caribe. Caracas: SELA.

Mallorquín, C. (2007). The unfamiliar raúl prebish. In E. Pérez, \& E. Vernego (Eds.), Ideas, policies and economic development in the Americas (pp. 98-122). London: Routledge.

Marini, R. M. (1973). Dialéctica de la dependencia. Mexico: Ediciones Era.

Márquez, H. (2007). Controversias en el desarrollo económico local basado en las remesas de los migrantes. Análisis económico, 47, 307-330.

Covarrubias, H. M. (2009). Diez rostros de la crisis civilizatoria del sistema capitalista mundial. Problemas del Desarrollo, 40, 191-210.

Covarrubias, H. M. (2010). La gran crisis del capitalismo neoliberal.
Andamios, 13, 57-84.

Munck, R. (2000), Dependency and imperialism in Latin America. In R. Chicolte (Ed.), The political economy of imperialism (pp. 141-156). Lanham, MD: Rowmann \& Littlefield.

Petras, J., \& Veltmeyer, H. (2000). Globalisation or imperialism? Cambridge Review of International Affairs, 14, 1-15. doi:10.1080/09557570008400327

Prebisch, R. (1986). El desarrollo económico en América Latina y alguno de sus principales problemas,” Desarrollo Económico, 26, 479-502.

Robinson, W. (2008). Latin America and global capitalism: A critical globalization perspective. Baltimore, MD: Johns Hopkins University Press.

Schierup C.-U., Hansen, P. \& Castles, S. (2006). Migration, citizenship, and the European welfare state: A European dilemma. London: Oxford University Press. doi:10.1093/0198280521.001.0001

Singa Boyenge, J. P. (2007). ILO database on export processing zones (Revised). Working Paper 25. Sectoral Activities Programme. Geneva: International Labour Organization.

Singer, H. (1975). The strategy of international development. Essays in the economics of backwardness. London: Macmillan.

Stiglitz, J. E. (2002). Globalization and its discontents. London: Penguin.

The Economist (2009). Manufacturing future: Wanted new costumers. The Economist, 393, 36-38.

UNCTAD (United Nations Conference on Trade and Development) (2005). World Development Report 2005. Transnational Corporations and the Internationalization of $R \& D$. New York, NY: United Nations

United Nations (2004). World economic and social survey 2004. International migration. New York, NY: United Nations.

Críticas de la Economía of Política (2006). Seguimiento de la población mundial, con especial referencia a la migración internacional y el desarrollo.

Klugman, J. (2010). Informe sobre desarrollo humano 2009. Superando barreras: movilidad y desarrollo humanos. New York, NY: United Nations.

World Bank (2010). Migration and Remittances Factbook 2011. URL (last checked 10 April 2012).

http://issuu.com/world.bank.publications/docs/9780821382189 